症例

胸骨縌骨折，両側多発肋骨骨折を伴った flail chest の 1 例

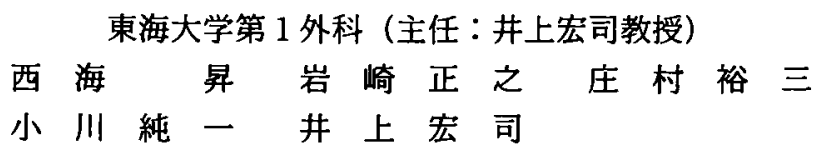

近年, 人工呼吸器の発達と集中治療の高度化に伴い, flail chest を伴う重症胸部外傷 の救命例が增加している. 今回われわれは, 68歳女性, 両側多発助骨骨折に繸方向への 胸骨骨折を伴った flail chestの 1 例を経験し，13日間の内固定術により治㾏せしめた. 胸骨骨折を伴う両側多発助骨骨折は，両側胸壁の前方型の flail chest となり，固定が邉 延し重症となりやすい. flail chest の治療法として, (1)人工呼吸器による内固定術, (2) 觀血的助骨固定術 (外固定術), (3)(1)と(2)の併用が挙げられる. 急性期の外傷患者に対し て, 内固定術は侵襲がほとんど無く, 他の重要臟器の治療に専念でき, 最近の人工呼吸 器や中心静脈栄養の発達により長期間の人工呼吸器管理が可能になったことより，われ われの施設では flail chest に対して内固定術を第一選択として治療してきた。この症例 の様に,胸骨骨折を伴う flail chest 症例においても内固定術は有用であると考えられる.

索引用語：胸骨骨折, flail chest

はじめに

従来より flail chest の治療法として, 人工呼吸器に よる内固定術と雉血的助骨固定術（外固定術）の 2 種 類が挙げられ，優劣が論議されている.今回われわれ は, 両側多発胁骨骨折に, 稀な縦方向への胸骨骨折を 伴った flail chest の 1 例を経験し, 内固定術により良 好な結果が得られたので報告する.

\section{症例}

68歳女性. 自転車走行中, 乗用車にはねられ, 他院 で救急処置後, 受傷 2 時間後に当院救命救急センター へ搬送された. 来院時, 意識レベルはJapan Coma Scale て II- 10 , 呼吸数 $40 /$ 分, 血圧 $80 / 50 \mathrm{mmHg}$, 脈拍 数126/分であった。左前胸壁は扁平に変形し, 吸気時 に楩山, 呼気時に突出する flail chest を呈していた。 血液ガス分析では room air で $\mathrm{PaO}_{2}$ 33torr, $\mathrm{PaCO}_{2}$ 30torr であった，他に蹎液鼻瘦・耳瘦を認め, 頭部 CT にて頭蓋底骨折を,腹部CTにて肝挫傷を認めた(表 1).

来院時の胸部 X 線単純写真において, 左第 1 第 5 肋骨は後方と側方, および肋軟骨部での 3 列で骨折し, anterior type, lateral type, posterior type の混合型

1994年12月22日受付 1995年 4 月 6 日採用
表 1 来院時血液検査

\begin{tabular}{|c|c|c|}
\hline \multicolumn{3}{|c|}{ 血液ガス分析 (room air) } \\
\hline & $\mathrm{pH}$ & 7.37 \\
\hline & $\mathrm{PaO}_{2}$ & 33 torr \\
\hline & $\mathrm{PaCO}_{2}$ & 30 torr \\
\hline & $\mathrm{BE}$ & -5.8 \\
\hline \multirow[t]{5}{*}{ 末血 } & WBC & $27,500 / \mu 1$ \\
\hline & $\mathrm{RBC}$ & $285 \times 10^{4} / \mu 1$ \\
\hline & $\mathrm{Hg}$ & $8.4 \mathrm{~g} / \mathrm{dl}$ \\
\hline & $\mathrm{Ht}$ & $25.2 \%$ \\
\hline & Plt & $23.7 \times 10^{4} / \mu 1$ \\
\hline \multirow[t]{3}{*}{ 生化学 } & GOT & $67 \mathrm{U} / l$ \\
\hline & GPT & $48 \mathrm{U} / l$ \\
\hline & CPK & $475 \mathrm{U} / l$ \\
\hline
\end{tabular}

の flail chest であった. 加えて，左第 6〜第 8 肋骨は 側方の 1 列で骨折していた. 一方, 右第 1 〜第 4 助骨 は後方と側方の 2 列で骨折していたが, 右胸壁は臨床 上明らかな flail chest は呈していなかった.さらに,両 側の肺挫傷と血胸, 上縦隔陰影の拡大を認めた(図 1).

T3レベルの胸部 CTで, 胸骨柄より胸骨体左側にか け $5 \mathrm{~cm}$ の縦方向への骨折と, 左右の多発助骨骨折に伴 う胸壁の変形を認めた(図 2).胸骨はシェーマの如く, 胸骨切痕より胸骨柄, 胸骨体左側にかけて縦方向に骨 


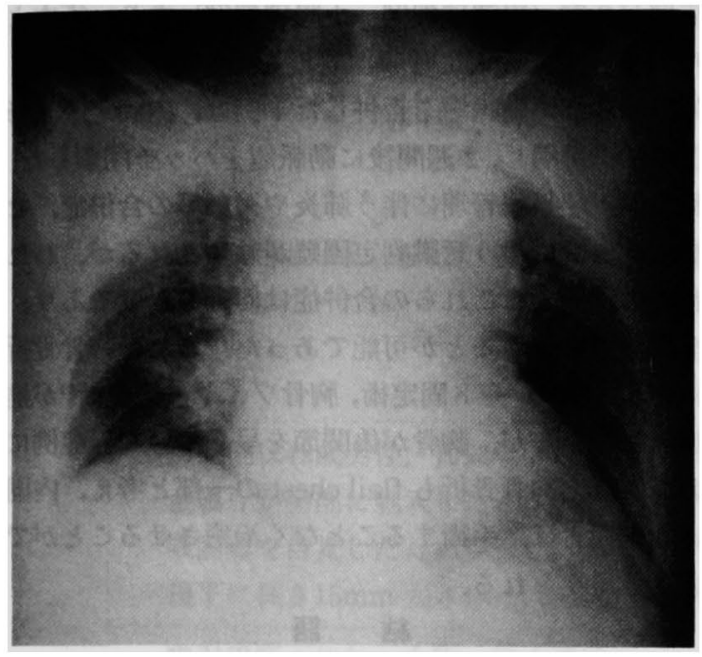

図 1 来院時胸部単純写真: 両側の多発助骨骨折, 肺 挫傷, 血胸を認めた。 上緹隔陰影の扡大を認め, 大 血管損傷の合併が疑われた。

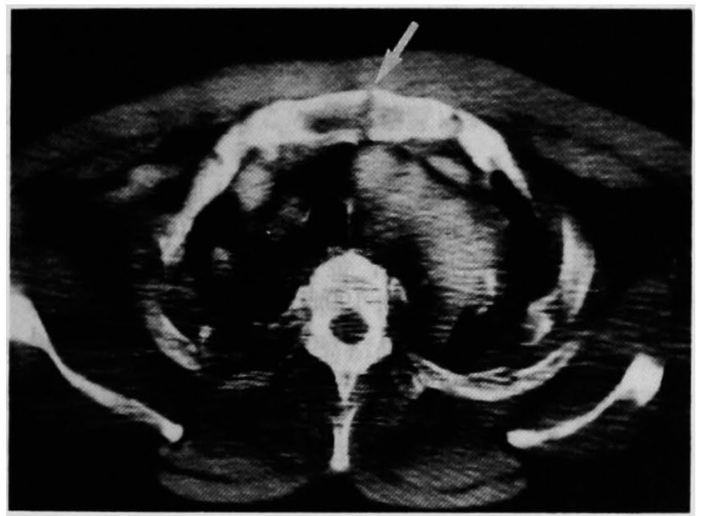

図 2 T3レベルの胸部 CT:胸骨柄に綐方向への骨折 を認めた (矢印)。T3・T4レベルのCTにて単純写 真で認めた上繸隔陰影の拡大は脂肪織の陰影と診断 し，大動脈損傷を否定した。

折していた(図 3 )。即ち，左側胸郭は胸骨骨折を加え ると 4 列で骨折し，flail chest を呈していた．直ちに 両側に胸腔ドレーンを㨂入し，気管内㨉管を行った。 来院 2 時間後よりPEEP $10 \mathrm{cmH}_{2} \mathrm{O}$ を加えた Contineous positive pressure ventilation (CPPV) で内固定術を開始した，2病日までは，心筋挫傷が主 因と思われる低血圧に対してDobutamin 等の強心用 が必要であったが， 3 病日より漸減可能となった。 7 病日に気管切開術を行い，13病日に flail chest の消失 を確認後, 人工呼吸器より weaning を開始し, 翌14病 日に離脱した．受傷 1 力月後には胸壁の変形と肺挫偒

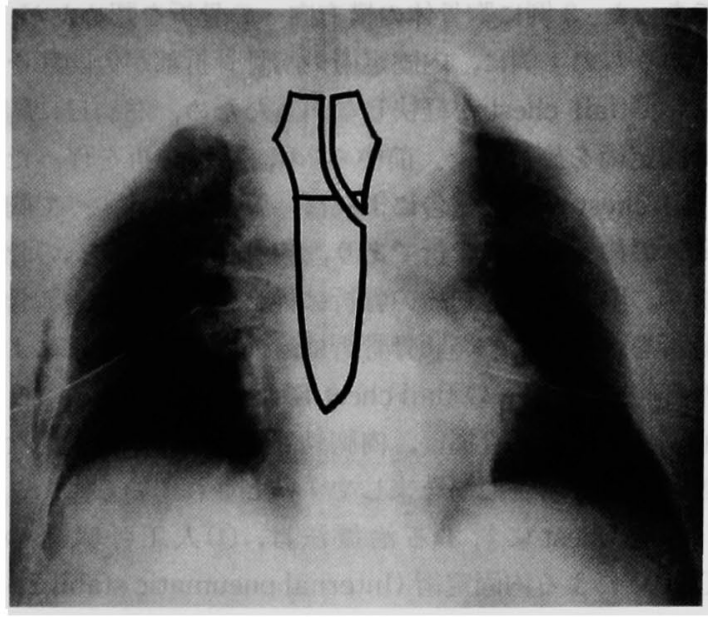

図 3 両側胸腔ドレーンと気管内㧴管啳の胸部単純写 真：胸骨柄より胸骨体左側にかけて繸方向への胸骨 骨折を認めた。

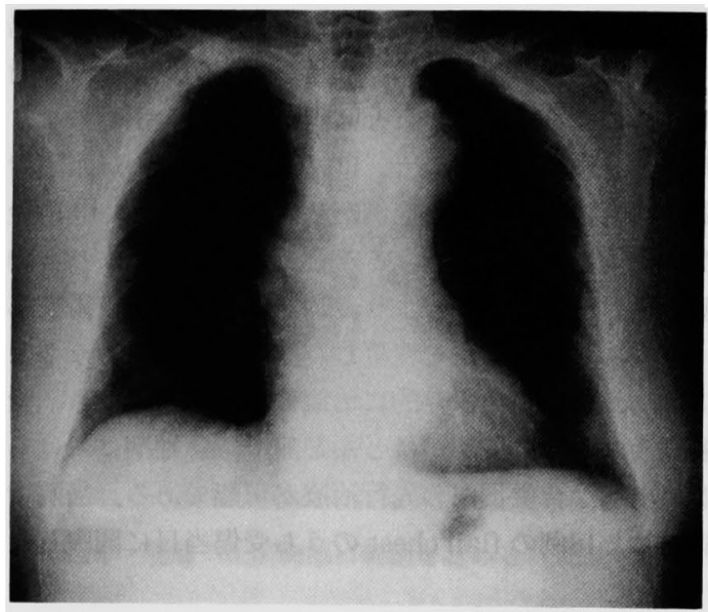

図 4 受侮 1 カ月後の胸部単純写真 : 胸壁の変形と肺 挫傷は軽快した。

は改善,頭蓋底骨折と肝挫傷は保存的治療により軽快, 35病日に退院した（図4）。

$$
\text { 考 察 }
$$

1988年 4 月より1994年 3 月までの 6 年間に，当科に 入院した鈍的胸部外傷患者は164例で，その11\%の18例 に flail chest を認め, 全例に内固定術を行い治痹に導 いた. 18例の平均年齢は51.2歳，CPPV の期間は平均 13.2 日, 人工呼吸器使用期間は平均 16.8 日であった。 頭部外傷を伴う 6 例は, 人工呼吸器使用期間が平均 18.2日と長期化していた。

flail chest に胸骨骨折を合併した症例を 4 例認めた が, 胸骨の綐方向への骨折を呈したのはこの症例のみ 
であった. 3 例に胸骨体の横方向への骨折を認めたが, そのうちの 1 例に，内固定術後胸骨骨折部が偽関節を 呈し, flail chest が軽快しなかったため，23病日に胸 骨固定術を施行した．前中ら”の，胸骨骨折を伴った flail chest 9 例の報告によれば, 胸骨骨折はすべて胸 骨体の横方向への骨折であり, 胸骨柄の横方向への骨 折や, 胸骨の緃方向への骨折は稀とされている.胸骨 骨折を合併する多発肋骨骨折は，前方からの衝撃によ り anterior type の flail chest になりやすく23)，また， 心筋挫傷, 大血管損傷, 内胸動静脈損傷, 脊髄損傷な ど，重症な合併損傷を来しやすいとされている。

flail chestに対する治療法は, (1)人工呼吸器の CPPV による内固定術 (Internal pneumatic stabiliza. tion), (2)セラミックピンやプレートを用いる外固定術 (External stabilizatin), (3)(1)と(2)の併用の 3 種類があ げられる.われわれは, flail chestに対する治療法と して，1988年迄は外固定術を施行してきたか，(1)外傷 に伴う一過性の黄疸に陥り遷延した症例が多く, 手術 や麻酔による肝機能障害と区別がつかず，手術により 悪化する恐れがあること, (2) Judet's struts が原因で 限局性の膿胸になった症例が 2 例あったこと, (3)術後 と退院後に疼痛が遷延すること, (4)内固定術よりも胸 壁の変形が著しいことより，1988年以降内固定術を第 一選択として治療法を変更した. 内固定術を行うこと により,肺挫倠を保存的に治疬に䢘け, 何よりも, 受 傷直後の患者に侵襲がほとんど無く，急性期における 他の重篤な合併損傷の先行治療が可能である. 当院で 経験した18例の flail chest のうち受傷当日に開腹した
症例が 2 例（胃脾破裂例，小腸破裂例）あり, 術中よ りIPPVによる人工呼吸器管理を行い治癋に導いた。 外傷性弓部偽動脈瘤を合併した 1 例は，内固定術と降 圧療法を併用し，2週間後に動脈瘤をパッチ閉鎖した。 長期人工呼吸器管理に伴う肺炎や褯創等の合併症, セ デーションに伴う意識判定困難が慗念されるが, われ われの症例ではこれらの合併症は何れも軽度であり, 全例治痖に導くことが可能であった.また，胸骨骨折 に対して,プレート固定術, 胸骨ワイヤー固定術“が推 奖されているが，胸骨が偽関節を呈していない症例に おいては，胸骨骨折も flail chest の一部と考え，内固 定術を行えば，手術することなく治㦄させることがで きると考えられる。

\section{結語}

1. 稀な縦方向への胸骨骨折を伴う flail chest $の 1$ 例を経験し，内固定術により治府した。

2. 過去 5 年間に18例の flail chest を経験し, 内固定 術で良好な結果を得た。

本論文の要旨は, 第87回日本胸部外科学会関東甲信越地 方会にて発表した。

\section{文献}

1) 前中由己, 加藤良一, 堀之内宏久:助骨骨折, 胸骨 骨折, Flail Chest. 救急医 $14: 1570-1576,1990$

2）今泉 均, 浅井康文, 金子正光: Flail Chest. 救 急医 18:827-830, 1994

3) W Hills. Sternal Fractures: Associated injuries and management. J Trauma $35: 55-60$, 1993

4）浅井康文, 山岸真理,堀江信治：外偒性胸骨完全骨 折の 3 治駼例. 胸部外科 $35: 714-717,1982$

\title{
A CASE OF FLAIL CHEST ASSOCIATED WITH LINEAR FRACTURE OF THE STERNUM AND MULTIPLE FRACTURE OF THE BILATERAL RIBS
}

\author{
Noboru NISHIUMI, Masayuki IWASAKI, Yuzo SHOMURA, \\ Junichi OGAWA and Hiroshi INOUE \\ First Department of Surgery, Toaki University School of Medicine
}

With a recent development of artificial respirator and intensive care, patients with severe chest trauma associated with flail chest can be increasingly saved. This time we experienced a 68 -year-old woman with flail chest associating with linear fracture of the sternum and multiple fracture of the bilateral ribs who was successfully cured by 13-day internal fixation. In general, multiple fracture of the bilateral ribs with sternum fracture often becomes anterior type flail chest in the chest wall to cause delayed fixation, leading to a critical condition. Treatments of flail chest include (1) internal fixation due to an artificial respirator, (2) intermittent rib fixation (external fixation), and (3) combinated use of (1) and (2). For traumatic patients in an acute phase, we have employed the internal fixation as the first choice, because it is least invasive; permits to devote ourselves to the treatment of other important organs; and recent development of artificial respiratory and intravenous hyperalimentation affords a long-term management with artificail respirator. In patients with flail chest with fracture of the sternum like this case, the internal fixation appears valuable. 